\title{
Reflections on Continuity, Change, and Historical Consciousness
}

\author{
Gabriel A. Reich \\ Department of Teaching and Learning \\ School of Education \\ Virginia Commonwealth University \\ greich@,vcu.edu
}

One of the greatest historical traumas experienced in the United States was our Civil War. Over 600,000 Americans died in that war, and chattel enslavement - described in Mississippi's 1861 secession declaration as "the greatest material interest of the world" (Civil War Trust, 2017) — was abolished. The rebelling southern states were devastated. African Americans, long depicted as form of degraded farm animal, had proved themselves equal in humanity and battle and were voted into power across the South. In the 150 years since the war ended, Americans have managed the war's trauma by constructing accounts that organize the carnage around great moral truths (Blight, 2001; Cobb, 2005). Equality was one of those moral truths, but it was eclipsed by a spirit of reconciliation that bound North and South together around a shared ideology of White supremacy. White supremacy became the "moral" and "scientific" truth that justified the restoration of racialized power and ended the brief experiment in social and political equality. The triumph of that restoration was commemorated by commissioning monuments to the Confederacy and placing them in prominent spaces in cities and towns (Leib, 2002). Cast in bronze and placed upon granite pedestals, they were built to last.

I was raised in New York City where I encountered a different collective memory of that troubled past - a victorious narrative in which the anti-slavery North elected Abraham Lincoln, the South seceded to defend slavery, the North won, and slavery was abolished. Even though my family spent the 1860s in Eastern Europe, I could share in that memory and the self-satisfied historical consciousness of the Civil War. It was not until I encountered Richmond Virginia's Monument Avenue that the enduring trouble of that past came into clearer focus. Monument Avenue is the iconic heart of the former capital of the Confederacy, and is dotted with statues of its soldiers and statesmen, such as Robert E. Lee, Stonewall Jackson, and Jefferson Davis (Leib, 2002).

I was shocked. Through my northern eyes, I saw traitors who would destroy the nation to protect the right to enslave. I was not meant to see traitors there, but rather the romantic ideals of a Lost Cause whose permanence would endure, standing firm against the tides of change (Leib, 2002). Perhaps the size of the monuments reflected the size of the shame they hid. Richmond was not only the capital of a failed rebellion, but it was also North America's second largest emporium of human chattel (Baptist, 2014). Coffles of enslaved men, women, and children were bound at the neck and taken from the city at night, a cloak of darkness covered up the shameful source of the city's wealth (Baptist, 2014). After losing a Civil War to protect those profits, Richmond masked its shame with bombast, presenting the symbolic power of White supremacy in stone, bronze, and concrete.

After settling in Richmond, my initial shock at the monuments faded and I slowly became acclimated to them. Some of the bronzes are exceptionally well wrought works of art 
and over time and repetition they became part of the scenery — pretty statues on a beautiful avenue. The addition of a monument to African American tennis champion and human rights activist Arthur Ashe in 1996 served to append the narrative told on that avenue, but only slightly (Leib, 2002). The Ashe monument was like a sidebar in a textbook, something you might get a test question on, but probably not.

In the Fall of 2016, I spent time in the art and English classrooms of two White teachers of predominantly African American students. Together these classes explored, contextualized, interpreted, and reacted to those works of public art and the intentions of those who erected them. In addition to discipline-specific learning goals related to the interpretation and production of art and rhetoric, the teachers also wanted their students to take bold critical stands. In particular, the art teacher explicitly drew a connection between the ideology of White supremacy that those statues represent and racial inequality today. The students were aware that the ideological purpose of the monuments was antagonistic to them personally and to their interests collectively, but their ideas about what ought to be done with them were very diverse. I was surprised that only one of the ten students who participated in the study suggested the statues be removed. The passage of time confers upon the monuments the status of tradition, which may, in part, have justified their continued presence to the students (Rüsen, 2012). The students' resigned acceptance of the monuments continued existence may also have been due, in part, to their awareness that removal of the statues would be likely to bring a White backlash. Either way, such a move may just have seemed more trouble than it was worth.

I too experienced resignation as repetition replaced shock. As the violence those monuments represent faded from my conscious awareness, I grew uncomfortable with my comfort. I thought, as did our new Mayor, that the addition of signs interpreting the monuments as Lost Cause propaganda would be a modest step towards truth if not reconciliation (Ferguson, 2017). I also believed that the addition of temporary public art installations could be juxtaposed with the Lee monument to inspire thoughtful reflection and dialogue. At the very least, such works could provoke periodic shocks that bring the ugly truth of the monuments back into consciousness. Instead, shock came in the form of a neo-Nazi riot to "protect" another Lee monument an hour away in Charlottesville, Virginia that left a woman dead and a city terrorized (Hanna, Hartung, Sayers, \& Almasy, 2017). Charlottesville impressed upon me that there are those who would kill, and perhaps die, to prevent their heroes from being brought down from pedestals. After Charlottesville, the mayor's proposal and my own no longer seemed adequate.

Historical consciousness is a product of moral sensibility as much as knowledge or epistemological sophistication (Rüsen, 2005). When that moral sensibility is shocked, the narratives that orient us in time and space are disrupted, making a change in consciousness more possible (Badiou, 2012/1993). The ugliness on display in Charlottesville shocked many White people to a distance that allowed us to glimpse the symbolic power of White supremacy. Even Richmond's conservative newspaper has called for the removal of the monument to Confederate President Jefferson Davis (Richmond Times Dispatch, 2017).

For thousands of years, humans have attempted to create a continuity of historical consciousness by erecting monuments. Historical consciousness, however, is much more malleable, rendering monuments anachronistic long before they turn to dust. Confederate 
monuments have re-emerged in our consciousness. For some they represent anachronism, for others, a powerful connection to the past. That these monuments also represent White supremacy, however, is clearer for many now than it was a short time ago. The conflict over their enduring presence is this generation's attempt to reckon with that troubled past.

History and social studies teachers can play an important role in such a reckoning. Whatever pedagogical path teachers choose to take, one of the greatest contributions they can make to expanding their students' historical consciousness is to design experiences in which what is taken-for-granted becomes an object of study. Historicizing the monuments and the recurring controversies regarding them can help students to begin to make sense of the relationship between ideology and the built landscape they likely take for granted (Gibson \& Reich, 2017). In the case of Confederate monuments, their greatest power may be in the way they have become part of the scenery in cities and small towns in the U.S. South and beyond. Historicizing them can help students to connect the past to the present, to see that what is "natural" is the result of historical contexts, and the choices people made within those contexts. That epiphany, cathartic for some, disquieting for others, is a moment where growth has a chance to begin.

\section{References}

Badiou, A. (2012). Ethics: An essay on the understanding of evil. (P. Hallward, Trans.). New York, NY: Verso. (Original work published in 1993)

Baptist, E. E. (2014). The half has never been told: Slavery and the making of American capitalism. New York, NY: Basic Books.

Civil War Trust. (2017, September 17). Primary source: The declaration of causes of the seceding states. Retrieved from https://www.civilwar.org/learn/primarysources/declaration-causes-seceding-states

Cobb, J. C. (2005). Away down south: A history of southern identity. New York, NY: Oxford University Press.

Ferguson, L. (2017, June 22). Mayor Stoney announces commission for statues on Monument Avenue. RVA Magazine. Retrieved from https://rvamag.com/news/mayor-stoneyannounces-commission-on-confederate-statues-for-monument-avenue.html

Gibson, M. T., Reich, G. A. (2017). Confederate monuments: Heritage, racism, anachronism, and who gets to decide? Social Education, 81(6), 356-362.

Hanna, J., Hartung, K., Sayers, D. M., \& Almasy, S. (2017, August 13). Virginia governor to white nationalists: "Go home... shame on you." CNN. Retrieve from http://www.cnn.com/2017/08/12/us/charlottesville-white-nationalists-rally/index.html

Leib, J. I. (2002). Separate times, shared spaces: Arthur Ashe, Monument Avenue, and the politics of Richmond, Virginia's symbolic landscape. Cultural Geographies, 9, 286-312.

McPherson, J. M. (2003). Battle cry of freedom: The civil war era (2nd ed.). New York, NY: Oxford University Press. (Original work published in 1988)

Richmond Times Dispatch (2017, August 26). Editorial: Take down the Jefferson Davis monument. Richmond Times Dispatch. Retrieved from http://www.richmond.com/opinion/our-opinion/editorial-take-down-the-jefferson-davismonument/article 463d1870-51b4-5d13-8f22-bfb015b01ca9.html 
Rüsen, J. (2012). Tradition: A principle of historical sense-generation and its logic and effect in historical culture. History and Theory, 51(4), 45-59.

Rüsen, J. (2005). History: Narration, interpretation, orientation. New York, NY: Berghahn Books. 